\section{Response to: 'External validation of EULAR/ACR classification criteria for idiopathic inflammatory myopathies' by Luu et al}

We would like to thank Luu $e t \mathrm{al}^{1}$ for their comments on our recent publication in the Annals of the Rheumatic Diseases, entitled 'First external validation of sensitivity and specificity of the European League Against Rheumatism (EULAR)/American College of Rheumatology (ACR) classification criteria for idiopathic inflammatory myopathies with a Japanese cohort'.

We are pleased to know similar validation studies of the new criteria $^{3-7}$ have been carried out to strengthen our contention. Although Luu $e$ al $^{1}$ argue that earlier studies have been published before ours, they were not found with the PubMed search, using the name of the new criteria and validation as keywords, at the time of the submission of our manuscript in April 2019. Presumably, so did the reviewers of our manuscript. Before our publication, Luu et al gave their presentation in scientific meetings in $2018,{ }^{34}$ which was followed by an official publication in the middle of $2019 .{ }^{5}$ It is common that presentations at scientific meetings precede the final and formal publication. The meeting abstracts do not appear in the literature databases, reflecting their possible scientific immaturity. In this regard, we gave oral presentations of our study at the meetings including the 13th International Workshop on Autoimmunity and Autoantibodies held in 2016. Nevertheless, we would like to point out that they made precious suggestion: inclusion of MRI or an extended antibody panel should improve the accuracy of the criteria.

A single-centre study reported by Hočevar $e t ~ a l^{6}$ was small in scale and retrospective but valuable. In a correspondence report, they raised the possibility of low sensitivity of the new criteria.

A larger retrospective report by Zhang et $a l^{7}$ published in May 2019, also described that the new criteria showed high sensitivity and specificity. We agree with their suggestion that 'other DM-associated rashes, such as technician's hand, shawl sign and $\mathrm{V}$ area rash, may be included in the classification tree to improve the performance of the criteria in the future'.

Taken together, all of the above studies are greatly informative, suggesting overall high performance of the new criteria and possible difference in sensitivity and specificity among different ethnicities. They also show us what to be done in the future to improve the criteria.

\footnotetext{
Masatoshi Jinnin ㄷ, , ${ }^{1}$ Akiko Ohta, ${ }^{2}$ Hitoshi Kohsaka ${ }^{3}$

${ }^{1}$ Department of Dermatology, Wakayama Medical University, Wakayama, Wakayama, Japan

${ }^{2}$ Division of Public Health, Department of Social Medicine, Saitama Medical

University, Moroyama, Saitama, Japan

${ }^{3}$ Rheumatology Center, Chiba-Nishi General Hospital, Chiba, Japan
}

Correspondence to Dr Hitoshi Kohsaka, Rheumatology Center, Chiba-Nishi General Hospital, Chiba, 270-2251, Japan; kohsaka-mdr@umin.ac.jp

Handling editor Josef $S$ Smolen

Contributors Drafting of the manuscript: MJ, AO. Critical revision of the manuscript: HK.

Funding The authors have not declared a specific grant for this research from any funding agency in the public, commercial or not-for-profit sectors.

Competing interests None declared.

Patient and public involvement Patients and/or the public were not involved in the design, or conduct, or reporting, or dissemination plans of this research.

Patient consent for publication Not required.

Provenance and peer review Commissioned; internally peer reviewed.

(C) Author(s) (or their employer(s)) 2020. No commercial re-use. See rights and permissions. Published by BMJ.

\section{D) Check for updates}

To cite Jinnin M, Ohta A, Kohsaka H. Ann Rheum Dis Epub ahead of print: [please include Day Month Year]. doi:10.1136/annrheumdis-2020-217635

Received 23 April 2020

Accepted 23 April 2020

\section{Linked}

- http://dx.doi.org/10.1136/annrheumdis-2020-217568

Ann Rheum Dis 2020;0:1. doi:10.1136/annrheumdis-2020-217635

ORCID iD

Masatoshi Jinnin http://orcid.org/0000-0001-9230-6207

\section{REFERENCES}

1 Luu Q, JH A D, Hall A, et al. External validation of EULAR/ACR classification criteria for idiopathic inflammatory myopathies. Ann Rheum Dis.

2 Jinnin M, Ohta A, Ishihara S, et al. First external validation of sensitivity and specificity of the European League Against Rheumatism (EULAR)/American College of Rheumatology (ACR) classification criteria for idiopathic inflammatory myopathies with a Japanese cohort. Ann Rheum Dis 2020:79:387-92.

3 Luu Q, Major G. Performance of the 2017 European League against rheumatism / American College of rheumatology (EULAR/ACR) classification criteria for adult idiopathic inflammatory myopathies (IIM) in clinical practice in an Australian cohort. J Intern Med 2018;48:7

4 Luu Q, Day JH A, Limaye V, et al. Performance of the 2017 European League against rheumatism / American College of rheumatology (EULAR/ACR) classification criteria for adult idiopathic inflammatory myopathies (IIM) in an Australian cohort. Arthritis Rheumatol 2018;70.

5 Luu Q, Day J, Hall A, et al. External validation and evaluation of adding MRI or extended myositis antibody panel to the 2017 EULAR/ACR myositis classification criteria. ACR Open Rheumatol 2019;1:462-8.

6 Hočevar A, Rotar Z, Krosel M, et al. Performance of the 2017 European League against Rheumatism/American College of rheumatology classification criteria for adult and juvenile idiopathic inflammatory myopathies in clinical practice. Ann Rheum Dis 2018;77:e90-e.

7 Zhang X, Yang X, Ji L, et al. Validation of 2017 classification criteria for adult and juvenile idiopathic inflammatory myopathies proposed by EULAR/ACR in Chinese patients. Int J Rheum Dis 2019;22:1278-82. 